Article

\title{
Do behavioral, educational, and legal factors determine the applicability of forensic accounting in the public sector?
}

\author{
Sagir Lawal ${ }^{1 *}$, Junaidu Muhammad Kurawa², Kabir Tahir Hamid ${ }^{3}$ and Umar Habibu Umar ${ }^{4}$ \\ 1 Department of Accounting, Nigeria Police Academy Wudil, Kano, Nigeria; \\ email :sagirlawalimam9557@gmail.com \\ 2 Department of Accounting, Bayero University Kano, Nigeria; email : mmjndkurawa@gmail.com \\ 3 Department of Accounting, Bayero University Kano, Nigeria; email : khtahir2004@yahoo.com \\ 4 Department of Accounting, Yusuf Maitama Sule University, Kano, Nigeria; email : uhumar21@gmail.com \\ * Correspondence: sagirlawalimam9557@gmail.com; Tel.: +2347060979557
}

Received: 25 December 2020; Accepted: 4 March 2021; Published: 20 March 2021

\begin{abstract}
This study examined the impact of educational, legal, and behavioral factors on the applicability of forensic accounting in the public sector in Nigeria. The study utilized primary data through the administration of questionnaires to accountants the internal and external auditors drawn from seven states of the North-Western geo-political zone of Nigeria. Partial Least Squares (PLS) path modeling using smart PLS3 Statistical Software was employed for the analysis. The findings indicated that behavioral, educational, and legal factors are positively related to the applicability of forensic accounting in the states. The results revealed the importance of giving special consideration to educational, legal, and behavioral factors to ensure the successful application of forensic accounting to deter and detect corruption and other fraudulent activities in Nigeria. The study shows how educational and professional institutions would assist in the promotion of the awareness, knowledge, and skills of forensic accounting.
\end{abstract}

Keywords: Forensic accounting; Educational factors; Legal factors; Behavioral factors; Fraud; Nigeria

JEL codes: M410, M420, M480

\section{Introduction}

The issue of corruption has become a daily concern for many countries across the globe not only in developing economies but also in developed ones (Suleiman and Ahmi, 2018). It is among the key threats to political and economic development in any country in the world, but its level and degree of occurrence vary from one country to another (Enofe et al., 2017). For example, in the past three decades, many high-profile financial reporting scandal cases have emerged, such as Enron, WorldCom, Parmalat, Satyam, sub-prime mortgages, Olympus (Rezaee et al., 2014; Rezaee et al., 2016). A survey carried out by the Association of Certified Fraud Examiners (ACFE) in 2014 disclosed that organizations across the globe lost nearly five percent of them to total annual income to fraudulent activities, with aggregate costs of about $\$ 3.7$ trillion and a median cost of over $\$ 140$ while more than one-fifth of fraudulent cases led to suffering losses of at least $\$ 1$ million (ACFE, 2014).

In specific, the Nigerian public sector has not yet been separated from corruption in one form or the other despite the efforts made by the current and previous administrations (Suleiman and Ahmi, 2018). In fact, in the past decades, Nigeria had been ranked among the top ten most corrupt nations in the world by Transparency International and other relevant international organizations (Ekpo et al., 2016). Despite the huge natural and human resources in the country, corruption becomes a clog in the 
wheel of the development of the country, as it has continually frustrated the achievement of its noble national goals (Ijewereme, 2015). It comes with various consequences that undermine the welfare and progress of people. For example, in Nigeria, social restless and problems like unemployment, youth restiveness, armed robbery, kidnapping for ransom are largely attributed to corruption (Ijewereme, 2015). It also contributes significantly to the provision of poor or no infrastructure in the country.

Since the 1970s, several attempts have been made to combat corruption in Nigeria by different administrations, such as the Jaji Declaration, Ethical Revaluation, the War Against Indiscipline (WAI), the Ethical and Social Mobilization Crusade, and War Against Indiscipline and Corruption. Also, since the return of democracy in 1999, the Independent Corrupt Practices and Other Related Offenses Commission (ICPC) and the Economic and Financial Crimes Commission (EFCC) were established to fight corruption. Unfortunately, corruption and other related fraudulent activities remain the key problems of the country. This is because an evaluation of antigraft/anti-corruption in Nigeria revealed that corruption would continuously be committed, as fraudsters fear no consequences (Ayobami, 2011). Currently, the two Nigerian anti-corruption commissions, ICPC and EFFC, have failed to combat and reduce it to the barest minimum in the country.

The need to find a better way of combating corruption and other related fraudulent activities in Nigeria in this period whereby even developed countries are complaining about a drastic fall in their revenues as a result of the COVID-19 pandemic is very profound. A very contemporary and effective technique of combating corruption and other related fraudulent activities that have been widely acknowledged is forensic accounting. It is not a new branch of accounting, as the skills and activities depicting it have been practiced for long without being called so (Pedneault et al., 2012). However, it was first conducted in the United States in the late 1870s and early 1880s because of the stock fraud cases and scandals found in the securities market and the credit industry (Rezaee et al., 2016). It evolved from the courts of law (Gray, 2008). The continuous rise in white-collar crimes forced educators, students, and professional associations to enter into the specialized field of fraud and forensic accounting (Bhavani et al., 2018). It appeared to provide litigation support, consulting, expert witnessing, and fraud investigation (Rezaee et al., 2014).

More so, recently Nigeria's debt profile became a topical issue for policymakers and development practitioners as recently the debt service-to-equity ratio is 60 percent as a result of the drastic fall in oil revenue (Onyekwena and Ekeruche, 2020). Many experts believe that Nigeria needs no debts to finance its budget provided that corruption and other fraudulent activities are deterred and detected. In other words, the available resources in Nigeria are enough to satisfy the needs and requirements of all Nigerians provided that corruption and other fraudulent activities are curbed. In Nigeria, corruption occurs in various forms, such as misappropriation, kickback, over-invoicing, bribery, embezzlement, tribalism, nepotism, money laundering, and outright looting of the treasury, among others (Ijewereme, 2015). Currently, Nigeria needs a better way of curbing corruption and other related fraudulent activities. According to Suleiman and Ahmi (2018), forensic accounting is the only best option to apply by Nigerian anti-corruption agencies to curb corruption in the country. Similarly, through an interview technique, the appropriateness of the application of forensic accounting to investigate and prosecute offenders in the public sector of Nigeria was established by Suleiman and Ahmi (2018). Besides, many empirical studies, such as Okoye and Gbegi (2013), Enofe et al. (2015), Joseph et al. (2016), Suryanto and Ridwansyah (2016), Okoye and Ndah (2019), and Umar et al. (2021) have established the effectiveness of forensic accounting in combating corruption and other related fraudulent activities.

Hence, to ensure successful and continuous use of forensic accounting in detecting and preventing fraudulent activities, this study seeks to establish the key determinants of its applicability in the Nigerian public sector. Based on a literature survey, education, legal and behavioral factors are very vital in ensuring its successful application.

The remainder of the paper is structured into four sections. Section 2 provides a literature review and hypothesis development. Section 3 presents the methodology used in the research. Section four contains results and discussion. Finally, section 5 accommodates a conclusion, recommendations, and limitations of the study. 


\section{Literature Review and Hypothesis Development}

The fact is that there is no universally accepted and all-encompassing definition of forensic accounting. The definition mainly depends on the background, experience, and practice of each forensic accountant (Pedneault et al., 2012). It has been seen as the application of science and technology for investigating and exposing fraudulent and other illegal activities in the fields of accounting, finance, management, criminology, and other areas where such activities could occur (Rezaee et al., 2014). Services offered by forensic accountants involve business purchases, the valuation of divorce assets, property damage, lost profits caused by embezzlement and other illegal activities, tax evasion, and money laundering practices (Gray, 2008). Moreover, AICPA described forensic accounting to involve the application of two forms of knowledge:

- Fundamental knowledge, such as laws, courts, and dispute resolution, planning and preparation, information gathering and preserving, discovery, reporting, experts and testimony, and;

- Specialized forensic knowledge, such as bankruptcy, insolvency and reorganization, computer forensic analysis, economic damages calculations, family law, financial statement misrepresentation, fraud prevention, detection and response, and business valuation (Pedneault et al., 2012; pp. 3-4).

Briefly, it is understandable from the above that forensic accounting entails the application of accounting techniques and concepts in issues concerning legal matters. The concept has been introduced due to the high rate of white-collar crimes like embezzlement, fraudulent financial practices, and other various financial misconducts. In the world of finance, most of the economic damages are caused by the white-collar crime (Rezaee et al., 2014). This gave birth to the emergence of forensic accounting into the world (Bhavani, et al., 2018). Therefore, the role of forensic accounting in minimizing white-collar crimes and other irregularities is very profound.

Many factors influence the application of forensic accounting, such as the educational, the legal, the behavioral, the political, and the environmental. However, for this study, education, legal and behavioral factors are considered. Discharging forensic accounting services requires forensic accountants to acquire certain special skills and knowledge, as earlier mentioned. It is, therefore, an important factor that influences the applicability of forensic accounting services.

In other words, forensic accountants are required to have certain knowledge and skills, such as auditing, investigative knowledge, criminology, accounting, legal, information technology, and communication skills, among others (Oyedokun, 2012). The major sources of forensic accounting knowledge and skills are educational and professional institutions. These institutions perform a critical role in the dissemination of forensic accounting knowledge and skills. Many universities and other educational institutions, particularly in developed nations, have introduced forensic accounting courses into their various academic programs. However, Eme (2013) disclosed that Nigerian universities are not yet prepared to take up forensic accounting courses. Hence, many calls have been made for the integration of forensic accounting education into accounting curricula in universities (Alabdullah et al., 2014; Rezaee et al., 2014; Efiong et al., 2016; Ramadhan, 2016; Bhavani et al., 2018; Ejike, 2018; Kumshe et al., 2018). Not only universities, polytechnic, and other advanced education institutions should introduce forensic accounting courses into their various accounting programs. This is because the lack of inclusion of forensic accounting in some countries like in Iraqi university curricula has been contributing significantly to the increase in financial fraud and corruption in the country (Alabdullah et al., 2014). The introduction of the course is needed because educational institutions play an essential role in the construction, interpretation, and reinforcement of societal values by spreading and transferring knowledge. Besides, they produce accountants to be absorbed in various public and private organizations. Therefore, acquiring forensic accounting skills would be of great help to them and the organizations.

Besides, professional institutions have been performing a vital role in qualifying and certifying people to become competent forensic accountants. Therefore, they actively engage in disseminating the knowledge and skills of forensic accounting among their members and non-members through examination, training, and lectures. Today, many professional associations and institutions regulate 
the practice and dissemination of such knowledge and skills. Such institutions include the Association of Certified Fraud Examiners, National Association of Certified Valuation Analysts, American Institute of Certified Public Accountants, American College of Forensic Examiners, Association of Certified Fraud Specialists, National Litigation Support Services Association, and the Institute of Business Appraisers (Gray, 2008). A similar institution known as the Institute of Forensic Accountants of Nigeria (IFA) exists in the country to support forensic accounting services (Umar et al. 2021). However, this Nigerian institution is still struggling to have an enabling law. More so, the Institute of Chartered Accountants of Nigeria (ICAN) as a general Nigerian Accounting Professional body has an independent faculty for the dissemination of the knowledge and skills of forensic accounting. Moreover, these professional associations usually organize seminars and training for their members through a program known as Mandatory Continuing Professional Development (MCPD) to enable them to keep abreast of contemporary issues, which include forensic accounting. Interestingly, even non-members are allowed to participate.

Many empirical studies relevant to forensic accounting education were conducted. For example, Gbegi and Adebisi (2014) studied the role of forensic accounting skills and techniques in fraud investigation in the Nigerian public sector. The main data were collected from the staff of three anticorruption agencies that fight corruption in Nigeria through questionnaire administration. The findings established a significant positive relationship between forensic accounting skills and techniques and fraud detection and reduction in the Nigerian public sector. Rezaee et al. (2014) surveyed to explore experts' views on forensic accounting education and practice in China. One of the key findings is the need to infuse forensic accounting topics into business and accounting curricula in the country. Saito and Teresa (2016) examined four financial reporting fraudulent activities, such as Olympus, Parmalat, Satyam, and Longtop intending to find their implications. The results revealed the relevance of forensic accounting and auditing education to inculcate ethical conduct in future managers and business persons to promote their ethical thinking

Moreover, Wilson et al. (2017) administered questionnaires to academics and practitioners to explore the prospects and challenges of forensic accounting in Nigeria. The study revealed an increase in the demand for forensic accounting services. Hence, forensic accounting education should be integrated into educational curricula to meet up the market demand for its services. Bhavani et al. (2018) explored views on the relevance of forensic accounting education in the United Arab Emirates (UAE) from various participants, such as educators, executives, and students. The results indicated that little attention was paid to forensic accounting education as it has not been adequately integrated into the Emirate University curricula of graduate and postgraduate programs.

Briefly, through educational and professional associations the knowledge and skills of forensic accounting could be disseminated and enable it to be successfully applied. Hence, it is hypothesized that:

$\mathrm{H}_{1}$ : Educational factors will significantly contribute to the applicability of forensic accounting in Nigeria.

Earlier mentioned forensic accounting entails making a presentation of a report to courts to resolve civil and criminal litigation cases. Forensic accounting evolves to resolve legal disputes in courts of law (Gray, 2008). Hence, the importance of the existence of effective laws to support the applicability of forensic accounting is very profound. In Nigeria, the weak judicial system is among the key problems faced by forensic accountants in discharging their duties (Ejike, 2018). Basic legal issues of forensic accounting include litigation support and expert witnessing in the court of law. Hence, there must be enabling laws that allow forensic accountants to discharge both litigation support and expert witnessing services effectively. Forensic accountants render two kinds of service, litigation support, and expert witness. In the case of litigation supports, forensic services are provided to an attorney which comprise services related to fact-finding (in the discovery and analysis of accounting data), damage calculations, and the preparation of demonstrative evidence (AICPA, 2008). Similarly, Albrecht et al. (2006) state that some of the key services rendered by forensic accountants to support litigation involve business litigation and dispute advisory to help lawyers in litigation processes. 
However, in the case of expert witnesses, litigation support services are extended and comprise the preparation of reports for various subject matters, such as tax analysis, economic fact-finding, and analysis of damage, which are required documented and testified as an expert witness in a courtroom. According to Gray (2008), forensic accountants may be required to provide evidence in civil and criminal cases by serving as expert witnesses to provide legally acceptable evidence in each case. Similarly, Melia (1991) asserts that in the case of expert witnesses, forensic accountants perform a vital role in trial actions (civil or criminal) whenever expert evidence is needed.

Briefly, to discharge forensic accounting services for litigation support and expert witness, there must be strong legal processes and a judicial system. Hence, it is hypothesized that:

$\mathrm{H}_{2}$ : Legal factors will significantly contribute to the applicability of forensic accounting in Nigeria.

Moreover, many studies exist on the behavioral aspects of the application of forensic accounting, which have to do with intention, associated risks, acceptance, benefits, pressure, etc., of applying forensic accounting. For example, Muthusamy (2011) investigated the determinants of the behavioral intention to apply forensic accounting services by large Malaysian companies to detect and prevent fraud. Through the administration of questionnaires, the findings revealed that attitude, organizational ethical climate, stakeholder pressure, and the perceived severity of fraud have significant positive impacts on the behavioral intention to use forensic accounting services. On the other hand, financial costs have a significant negative relationship with intention. Similarly, in Nigeria Efiong et al. (2016) evaluated the behavioral intention to apply forensic accounting techniques to detect and prevent fraud through the administration of questionnaires to some selected accounts from nine states and the Federal Capital Territory, Abuja. The study found that the acceptance of forensic accounting services by accountants was influenced by understanding the benefits, risks, fraud susceptibility, and fraud severity in their organizations. Ogbeide et al. (2017) administered questionnaires to mainly internal auditors, chief accountants, executive directors, and managers to establish the determinants of organizational intentions to apply forensic accounting services to detect and prevent fraud in Nigeria. The study found the perceived benefits and perceived risks of applying forensic accounting to have significantly affected the organizational intention to apply forensic accounting services to detect and prevent fraudulent activities. On the other hand, awareness and stakeholder pressures were found not to influence the intention to use the services. Thus, it is hypothesized that:

$\mathrm{H}_{3}$ : Behavioural factors will significantly contribute to the applicability of forensic accounting in Nigeria

\section{Methodology}

\subsection{Research Design}

The present study applied a quantitative cross-sectional survey design through the administration of questionnaires. The survey method was selected because it is the medium that measures the attitudes, knowledge, and preferences of respondents.

\subsection{Population of the Study}

The population of this study is made up of all the accountants, internal and external auditors, who are on Grade Level 12 and above in the Ministries of seven states of the North-West geo-political zone of Nigeria. Through contact with senior employees in the zone, the population was estimated to be around 1636 for 2019. The states comprise Jigawa, Kaduna, Kano, Katsina, Kebbi, Sokoto, and Zamfara.

\subsection{Sample Size and Sampling Techniques}

In survey research, determining an appropriate sample size is essential (Barlett et al., 2001). It is needed to minimize the total cost of sampling error (Kura, 2014). In determining the sample size for 
the study, the Taro Yamane 1968 formula was used to select a sample from the population. This technique was used by previous studies, such as Gbegi and Adebisi (2013), Adefila (2008), and Franklyn (2013). By applying the formula, a sample size of 321 was arrived at. However, to minimize the low response rate that could result from uncooperative respondents, the sample size of 321 was increased by 50 percent, which is 161, as suggested by Salkind (1997) and Kura (2014). Consequently, a sample of 482 was used for the study. A stratified sampling technique was applied to draw a sample from each state. Only 412 were returned, representing an 85.48 percent response rate. This rate falls above the acceptable recommended range of 40 percent -50 percent in social science study (Little, 1989). It is also satisfied the requirement of Sekaran (2003) and Hair et al. (2011), who considered a 30 percent response rate enough for a survey.

\subsection{Variables and their Measurements}

The study consisted of four variables. Three independent variables, educational, legal, and behavioral factors, as well as the applicability of forensic accounting as the dependent variable. These variables were adapted from previous studies and measured on a 5-point Likert scale, from strongly disagree (1) to strongly agree. The questionnaire was structured into two sections. Section one contains four items for the demographic information of the respondents. Sections two provide items measuring the variables of the study. The variables were measured as follows: applicability of forensic accounting, 13 items; educational factors, 5 items; legal factors, 3 items, and behavioral factors, 12 items.

Table 1. Variables and their Measurements

\begin{tabular}{|c|c|c|}
\hline $\begin{array}{c}\text { Latent } \\
\text { Variable }\end{array}$ & $\begin{array}{l}\text { Nature of } \\
\text { Variable }\end{array}$ & Source \\
\hline $\mathrm{AF}$ & Dependent & $\begin{array}{c}\text { Adapted from Imam (2013), Safiyanu et al. (2019); Efut \& Ema (2019), } \\
\text { and Rajab (2019) }\end{array}$ \\
\hline EFs & Independent & Adapted from Eme (2013), Saito \& Teresa (2016), Wilson, et al. ( 2017) \\
\hline less & Independent & Adapted from Hubber (2017) \\
\hline BFs & Independent & $\begin{array}{l}\text { Adapted from Muthusamy (2011), Muthusamy et al. (2010), and Eme } \\
\text { (2013). }\end{array}$ \\
\hline
\end{tabular}

Note. This table presents variables and their sources.

Figure 1. Research Framework

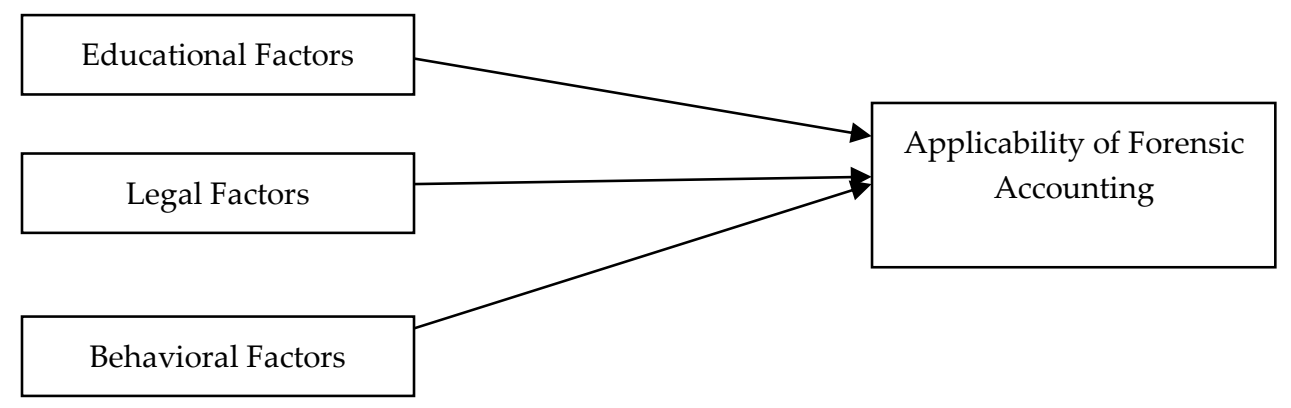

Note. This figure shows the research framework.

\subsection{Analysis Method}

This study uses the structural equation modeling (SEM) approach. There are three main reasons for using this approach. First, it is helpful to identify the predictive causal relationship (Baron \& Kenny 
1986). Second, it uses partial least squares (PLS) with confirmatory factor analysis (CFA) to test the hypotheses. This study used Software SmartPLS 3.2 to analyze the data. It performs two steps to analyze data using the outer model (measurement model) by using the PLS algorithm. Third, it analyses the inner model (structural model) through a bootstrap resampling technique.

\section{Results and Discussion}

\subsection{Demographic Profile of Respondents}

Table 2. Demographic Information of the Respondents

\begin{tabular}{|c|c|c|c|c|}
\hline & S/no. & Item & Frequency & Percentage \\
\hline \multirow[t]{3}{*}{1} & Office & Accountants & 212 & 54.08 \\
\hline & & Internal Auditors & 113 & 28.83 \\
\hline & & External Auditors & 67 & 17.09 \\
\hline \multirow[t]{4}{*}{2} & Experience & 10 years and below & 98 & 25.00 \\
\hline & & 11- 20 years & 95 & 24.23 \\
\hline & & $21-30$ years & 135 & 34.44 \\
\hline & & 31 years and above & 64 & 16.33 \\
\hline \multirow[t]{3}{*}{3.} & Educational qualification & OND/NCE/Advanced Diploma & 134 & 34.18 \\
\hline & & $\mathrm{HND} / \mathrm{BSc} / \mathrm{PDG}$ & 174 & 44.39 \\
\hline & & Masters and above & 84 & 21.43 \\
\hline \multirow[t]{6}{*}{4} & Professional qualification & ICAN & 39 & 9.95 \\
\hline & & CMA & 21 & 5.36 \\
\hline & & ANAN & 283 & 72.19 \\
\hline & & CPA & 14 & 3.57 \\
\hline & & CIA & 4 & 1.02 \\
\hline & & Others & 31 & 7.91 \\
\hline \multirow[t]{5}{*}{5} & Current position & Principal Acct./Auditor I & 80 & 20.41 \\
\hline & & Principal Acct./Auditor II & 106 & 27.04 \\
\hline & & Chief Accountant/ Auditor & 87 & 22.19 \\
\hline & & Ass. /Deputy Director Acc/Audit & 57 & 14.54 \\
\hline & & Director Account/Audit & 62 & 15.82 \\
\hline
\end{tabular}

Note. This table presents the demographic information of the respondents.

Table 2 presents the demographic information of 392 respondents. It shows that 212 (54.08 percent) are accountants, 113 (28.83 percent) internal auditors, and the remainder 67 (17.09 percent), external auditors. The respondents' years of working experience are that 98 ( 25.00 percent) have been working for 10 years and below, 95 (24.23 percent) between 11 and 20 years, 135 (34.44\%) 21 and 30 years, and 64 (16.33 percent) 31 years and above. Concerning educational qualification, 134 (34.18 percent) have OND/NCE/Advanced Diploma certificates, 174 (44.39 percent) HND/BSc/PDG, and 84 (21.43 percent) Masters and above. In the case of professional qualification, 39 (9.95 percent) are members of the Institute of Chartered Accountants of Nigeria (ICAN), 21 (5.36 percent) Certified Management Accountant (CMA), 283 (72.19 percent) the Association of National Accountants of Nigeria (ANAN), 14 (3.57 percent) Certified Public Accountants (CPA), 4 (1.02 percent) and 31 (7.91 percent) others. Besides, 80 (20.41 per cent) are currently in the position of Principal Accountant/Auditor I, 106 (27.04 per cent) Principal Accountant/Auditor II, 87 (22.19 per cent) Chief Accountant/Auditor, 57 (14.54 per cent) Assistant/ Deputy Director Account/Audit and 62 (15.82 per cent) Director Account/ Audit. 


\subsection{Data Screening}

In conducting any multivariate analysis, significant data editing and screening are vital. This is because the quality and the meaningful outcome of the analysis depend more or less on the initial data cleaning. Thus, missing data, outlier, normality, and linearity was checked and treated accordingly.

\subsection{Measurement Model}

The purpose of a measurement model is to find the validity and reliability of the items of variables (Faruk, 2018). Two tests were conducted, convergent validity and discriminant validity. This study performed internal consistency composite reliability (CR) to ensure the accuracy of the designed firstorder reflective constructs and factor loadings to evaluate the reliability of each item (Nunnally 1994). It also executes the average variance extended (AVE) to evaluate the construct's validity. As illustrated in Table 3, the factor loading values for all the informative indicators are above 0.5. It achieved the desired value, which is in line with the recommendation by several studies (Hair et al. 2012). The results of constructs achieved the desired composite reliability $(\mathrm{CR})>0.7$ and have gotten accepted AVE value $>0.5$, as presented in Table 3 .

Table 3. Convergent Validity

\begin{tabular}{cccc}
\hline Latent variable & Loadings & CR & AVE \\
\hline App_f10 & 0.754 & 0.881 & 0.515 \\
App_f1 & 0.749 & & \\
App_f12 & 0.781 & & \\
App_f13 & 0.720 & & \\
App_f14 & 0.577 & & \\
App_f7 & 0.723 & 0.882 & \\
App_f8 & 0.700 & & \\
Beh_f1 & 0.652 & & \\
Beh_f10 & 0.688 & & \\
Beh_f4 & 0.767 & & \\
Beh_f5 & 0.751 & & \\
Beh_f6 & 0.827 & 0.859 & \\
Beh_f7 & 0.671 & & \\
Beh_f8 & 0.668 & 0.753 \\
Leg_f2 & 0.905 & & \\
Leg_f3 & 0.829 & & \\
Edu_f2 & 0.784 & & \\
Edu_f3 & 0.813 & & \\
\hline
\end{tabular}

Note. This table presents the convergent validity of the constructs.

Table 3 shows the loadings of the respective items on their construct and all the loadings are above 0.5. It also shows that composite reliability (CR) is above the threshold of 0.7 and Average Variance Extracted (AVE) above the recommended value of 0.5.

Besides, discriminant validity explains how each variable is distinct from the other in the study. The study report in Table 4 using Fornell and Lacker Criterion and the Heterotraits-Monotraits Ratio.

Table 4 shows the discriminant validity using the Fornell and Lacker criterion for the variable of the study. It indicates that the diagonal and bold figure shows the square of the AVE and is above all the correlation of their respective loadings. Thus, the study satisfies the discriminant validity criterion. Hence, we shall check the next criterion.

In a similar view, the result of Table 5 shows the discriminant validity using the HeterotraitsMonotraits ratio. The threshold, as indicated by Henseler, et al. (2016), informed that none of the loadings should be above 0.9. Looking at the value, the highest is 0.661 . It indicates that the discriminant validity using the Heterotraits-Monotraits ratio is satisfactory. 
Table 4. Discriminant Validity

\begin{tabular}{ccccc}
\hline \multicolumn{2}{c}{ Fornell and Lacker Criterion } & & & \\
& Behavioral Factor & $\begin{array}{c}\text { Educational } \\
\text { Factor }\end{array}$ & Forensic Application & Legal Factor \\
\hline Behavioral Factors & 0.720 & & & \\
Educational Factors & 0.101 & 0.789 & & \\
Forensic Application & 0.534 & 0.149 & 0.718 & 0.867 \\
Legal Factors & 0.371 & -0.067 & 0.507 & \\
\hline
\end{tabular}

Note. This table shows the discriminant validity of the variables using the Fornell and Lacker criterion.

Table 5. Discriminant Validity

\begin{tabular}{|c|c|c|c|c|}
\hline \multicolumn{2}{|c|}{ Heterotraits-Monotraits Ratio } & \multirow[b]{2}{*}{ Educational Factor } & \multirow[b]{2}{*}{$\begin{array}{c}\text { Forensic } \\
\text { Application } \\
\end{array}$} & \multirow[b]{2}{*}{ Legal Factor } \\
\hline & Behavioral Factor & & & \\
\hline \multicolumn{5}{|l|}{ Behavioral Factor } \\
\hline Educational Factor & 0.172 & & & \\
\hline Forensic Application & 0.594 & 0.244 & & \\
\hline Legal Factor & 0.449 & 0.661 & 0.661 & \\
\hline
\end{tabular}

Note. This table shows the discriminant validity of the variables using the Heterotraits-Monotraits ratio

\subsection{Hypotheses Testing}

The results for testing the three formulated hypotheses are presented in Table 6 . It presents the relationship between the independent variables (behavioral, educational, and legal factors) and the dependent variable (applicability of forensic accounting).

Table 6. Structural Model (Bootstrapping)

\begin{tabular}{clrrrrr}
\hline S/no. & Hypothesis & $\beta$ & Std. error & t- value & p-value & Decision \\
\hline H1 & Edu_Factor - Forensic_App & 0.139 & 0.042 & $3.257^{* * *}$ & 0.001 & Supported \\
H2 & Leg_Factor -> Forensic_App & 0.379 & 0.046 & $8.074^{* * *}$ & 0.000 & Supported \\
H3 & Beh_Factor -> Forensic_App & 0.382 & 0.043 & $8.901^{* * *}$ & 0.000 & Supported \\
& Notes: ${ }^{* * *}$ Significant at 0.01 & R2 $=0.413, \quad$ R2 & Adjusted $=0.408$ & \\
\hline
\end{tabular}

Note. This table presents the results for testing the formulated hypotheses

Table 6 presents the bootstrapping procedure used for testing the formulated hypotheses as well as the significance between constructs (Henseler et al. 2014). The $\mathrm{R}^{2}$ depicts that educational, legal, and behavioral factors account for $41.3 \%$ of the changes in the applicability of forensic accounting in the states. It elucidates that all the constructs in the model are with a critical value of 1.96 for the twotailed test at a significant \%. Educational factors have been found to have a significant positive relationship with the applicability of forensic accounting. This finding justifies the position of earlier studies that showed the importance of forensic accounting education deterring and detecting fraudulent activities (Rezaee et al., 2014; Rezaee et al., 2016; Bhavani et al., 2018). Legal factors have significantly and positively influenced the applicability of forensic accounting. A similar result was also obtained in the case of behavioral factors, as they were also found to have a significant positive impact on the applicability of forensic accounting. This result supports earlier ones like Eme (2013) and Imam et al. (2015), who showed that the application of forensic accounting for the detection and prevention of fraud is largely influenced by the behavioral intention of practitioners to use it because of the perceived benefits of its usage.

Briefly, the results imply the need to give special attention to educational, legal, and behavioral factors to successfully apply forensic accounting to deter and detect fraudulent activities in Nigeria. 


\subsection{Discussion of Findings}

The study established educational, legal, and behavioral factors as key factors that significantly and positively influence the application of forensic accounting in the Northwestern states of Nigeria. In specific, the study found educational factors to have a significant positive contribution to the successful application of forensic accounting. Although forensic accounting is substantially inclined to accounting disciplines, it entails the combined application of various knowledge and disciplines like auditing, investigative knowledge, financial accounting, law, criminology, information technology, communication skills, etc. Hence, Umar et al. (2021) described it as a multi-skills practice because to efficiently and effectively discharge forensic accounting services skills and knowledge of various disciplines should be integrated. These skills and knowledge are often acquired through educational institutions. This reveals the indispensable role of higher-level educational institutions to promote forensic accounting. Many countries that have become successful in applying forensic accounting to deter and detect fraud have infused it into their educational curricula, particularly in universities. Consequently, many studies, such as Alabdullah et al. (2014), Rezaee et al. (2014), Ramadhan (2016), Bhavani et al. (2018), and Kumshe et al. (2018), among others, have strongly recommended the integration of forensic accounting into educational institution curricula. Recently, forensic accounting as a course is integrated into the latest Benchmark Minimum Academic Standards (BMAS) for Nigerian Universities issued by the National University Commission (NUC), Nigeria. Besides, some Nigerian universities have introduced forensic accounting as a core course. Other high certificate awarding institutions, such as polytechnic and colleges of education should also integrate forensic accounting into their curricula. Apart from educational institutions, relevant professional associations should also promote skills and knowledge by integrating it into their examination syllabi as well as spread its knowledge and skills through training, seminars, and Mandatory Continuing Professional (MCPD) programs.

Legal factors were also found useful in the applicability of forensic accounting in the Nigerian public sector. The fact is that since forensic accounting emerged from courts of law the importance of legal factors to its applicability is crucial. The basic duties of forensic accountants include litigation and expert witnessing where they are required to make presentations in a courtroom. The case for which forensic accountants to report may be civil or criminal. These duties could not be discharged effectively without a supportive legal system. In other words, there must exist enabling and clear laws to enable forensic accountants to discharge their duties hitch-free without having any bottlenecks, interruptions, and threats to allow justice to be done to offenders. The fact is that in Nigeria forensic accounting is at an infant stage with no strong statutory regulations (Akhimide and Ekatah, 2014). Hence, to make its application functional and effective supportive laws and other relevant regulations must be provided.

Moreover, behavioral factors are other important aspects found to affect the applicability of forensic accounting in the Nigerian public sector. These factors are humanistic in nature and largely revolve around awareness, understanding, intention, associated risks, and the acceptance to use forensic accounting services. To ensure the contribution of behavioral factors to its application, all stakeholders must be positively convinced to understand essential behavioral issues, such as the acceptance of forensic accounting services, understanding its benefits, associated risks, ethical climate, fraud susceptibility and severity in organizations, perceived pressures, etc. Understanding these positively would contribute immensely to the successful application of forensic accounting in Nigeria.

\section{Conclusion, Recommendations, and the Limitations of Study}

The objective of this study is to explore the factors influencing the applicability of forensic accounting in Nigeria. Specifically, three key factors, such as the educational, the legal, and the behavioral, were considered. Data were collected through the administration of questionnaires to accountants and auditors (internal and external) of various selected Ministries in the seven Northwestern geo-political zones of Nigeria. The results found educational, legal, and behavioral 
factors to have a significant impact on the applicability of forensic accounting in the states. The findings imply that to successfully apply its services, the educational, legal, and behavioral factors must be given special consideration. Based on the results, the study provides three key recommendations. First, all state and federal educational institutions (universities, colleges of education, and polytechnics) offering accounting and related courses should be compelled by their respective regulatory bodies to introduce courses related to forensic accounting into their curricula. Besides, all professional associations relevant to accounting should integrate it into their professional examination syllabi. They should also be among key topics to teach during their workshops, training, and Mandatory Continuing Professional Development Programmes. Second, all the necessary statutory laws and regulations should be provided to enable the hitch-free application of forensic accounting. Third, there should be massive campaigns through collaborations between the government, relevant professional bodies, and academic institutions to create awareness and see the benefits of forensic accounting so that it can be accepted by all stakeholders to reduce corruption and other related fraudulent activities in Nigeria.

Despite the contribution of this study, it has two key limitations. First, it is limited to three factors, educational, legal, and behavioral. Therefore, future studies should consider other essential determinant factors. Second, the sample of the study was narrowed to only the Northwestern zone out of six geopolitical zones. The restriction of movement due to the COVID-19 pandemic was among the major factors for restricting the study to that zone. Hence, future studies are encouraged to consider the remaining geopolitical zones.

Author Contributions: All authors contributed equally to the development of the manuscript.

Funding: The declare no external funding.

Conflicts of Interest: The authors declare no conflict of interest.

\section{Appendix A}

\section{QUESTIONNAIRE}

\section{DEMOGRAPHIC INFORMATION}

Please indicate your choice by ticking $(\sqrt{ })$ in the appropriate space provided in the response options:

A. Number of years in service

1- $\quad 0-10$

2- $\quad 11-20$

3- $21-30$

4- 31 and above

B. Highest Qualification

1. SSCE/GCE

2. $\mathrm{OND} / \mathrm{NCE}$

3. Bsc/HND/PGD

4. MASTERS and above

C. Membership of a professional body
( )

\section{( )}

( )

( )

( )

1. ICAN- Institute of Chartered Accountants of Nigeria. ( ) 
2. CMA- Certified management Accountant

3. ANAN- Association of National Accountants of Nigeria

4. CPA-Certified Public Accountant

5. CIA-Certified Internal Auditors

D. Current position

1. Principal Accountant I

2. Principal Accountant II

( )

3. Chief Accountant

4. Deputy Director Account

5. Director account

6. Principal Auditor

( )

7. Chief Internal Audit

( )

8. Deputy Director Audit

( )

9. Director Audit

\section{Appendix B}

Below are statements about the applicability of forensic accounting in the North-Western states, Nigeria. Please use the key below to select a number that indicates your level of agreement with the following statements.

5= Strongly Agree

4-=Agree

3=Undecided

2=Disagree

$1=$ Strongly Disagree

APPLICABILITY OF FORENSIC ACCOUNTING

\begin{tabular}{|c|l|c|}
\hline S/N & STATEMENT & Ranking 1-5 \\
\hline 1 & Forensic Accounting can be used in detecting and preventing corruption & \\
\hline 2 & Forensic Accounting can be used in detecting and preventing bribery & \\
\hline 3 & $\begin{array}{l}\text { Forensic Accounting can be used in detecting and preventing financial } \\
\text { mismanagement. }\end{array}$ & \\
\hline 4 & Forensic Accounting can be used in detecting and preventing frauds. & \\
\hline 5 & Forensic Accounting can be used in detecting and preventing thefts. & \\
\hline 6 & $\begin{array}{l}\text { Financial misconducts can be reduced to a minimal level with the application of } \\
\text { forensic accounting techniques at the state government in Nigeria. }\end{array}$ & \\
\hline 8 & $\begin{array}{l}\text { Financial misconducts can be prevented with the application of Forensic Accounting } \\
\text { at the state government level in Nigeria. }\end{array}$ & \\
\hline
\end{tabular}




\begin{tabular}{|c|l|l|}
\hline 9 & $\begin{array}{l}\text { The application of Forensic Accounting will go a long way in the fight against } \\
\text { financial misconduct at state government levels in Nigeria. }\end{array}$ & \\
\hline 10 & $\begin{array}{l}\text { The application of Forensic Accounting can prevent all financial misconduct at state } \\
\text { government levels in Nigeria. }\end{array}$ & \\
\hline 11 & $\begin{array}{l}\text { The existence of statutory audit will not affect the application of Forensic Accounting } \\
\text { in the prevention of financial misconduct at state government levels. }\end{array}$ & \\
\hline 12 & $\begin{array}{l}\text { The existence of the Association of Forensic Accountants can assist in obtaining legal } \\
\text { backing to the profession to assist prevention of financial misconduct at the state } \\
\text { government level. }\end{array}$ & \\
\hline 13 & $\begin{array}{l}\text { The need to prevent and detect financial misconduct in the public sector by the } \\
\text { citizens of states can encourage the applicability of forensic accounting. }\end{array}$ & \\
\hline 14 & $\begin{array}{l}\text { The service of Forensic Accountants is required at the state government level to } \\
\text { prevent and detect financial misconduct. }\end{array}$ & \\
\hline
\end{tabular}

\section{Appendix C}

Below are statements about Behavioral factors that can influence the applicability of forensic accounting in the North-Western States, Nigeria.

Please use the key below to select a number that indicates your level of agreements with the following statements 5= Strongly Agree

4-=Agree

3=Undecided

2=Disagree

$1=$ Strongly Disagree

\section{BEHAVIORAL FACTORS}

\begin{tabular}{|l|l|l|}
\hline S/N & STATEMENT & Ranking 1-5 \\
\hline 1 & $\begin{array}{l}\text { We currently use Forensic Accounting techniques for the prevention and detection of } \\
\text { financial misconducts in our establishment }\end{array}$ & \\
\hline 2 & $\begin{array}{l}\text { We intend to use Forensic Accounting techniques shortly in our establishment for } \\
\text { detection and prevention of financial misconducts }\end{array}$ & \\
\hline 3 & We cannot use Forensic Accounting because our staffs are not aware of the concept & \\
\hline 4 & We cannot use Forensic Accounting because it is expensive & \\
\hline 5 & $\begin{array}{l}\text { Forensic Accounting has come to stay hence our establishment will soon acquire its } \\
\text { services }\end{array}$ & \\
\hline 6 & $\begin{array}{l}\text { There are no enough tertiary institutions in states that could develop forensic } \\
\text { accounting curriculum to produce graduates of forensic accounting }\end{array}$ & \\
\hline 8 & $\begin{array}{l}\text { The existence of statutory audit will not affect the adoption of Forensic Accounting for } \\
\text { the prevention and detection of financial misconducts hence we are ready to use } t \text { in } \\
\text { our establishment }\end{array}$ & \\
\hline
\end{tabular}




\begin{tabular}{|l|l|l|}
\hline 9 & $\begin{array}{l}\text { The effort of the present administration of war against corruption encourage our } \\
\text { adoption of forensic accounting techniques for prevention and detection of financial } \\
\text { misconducts }\end{array}$ & $\begin{array}{l}\text { The existence of the Anti-Corruption Commission in our state government encourages } \\
\text { our need for forensic accounting services. }\end{array}$ \\
\hline 11 & $\begin{array}{l}\text { The legal environment is not conducive to create enabling law for the application of } \\
\text { Forensic Accounting at state and local governments }\end{array}$ & \\
\hline 12 & $\begin{array}{l}\text { There are no trained Accountants who will take up the Forensic Accounting profession } \\
\text { for its application at the state government level }\end{array}$ & \\
\hline
\end{tabular}

\section{Appendix D}

Below are statements of the educational factors that can influence the applicability of Forensic Accounting at state government levels in Nigeria.

Please use the key below to select a number that specifies your level of agreement with the following statements.

5. Strongly agree

4. Agree

3. Undecided

2. Disagree

1. Strongly disagree

\section{EDUCATIONAL FACTORS}

\begin{tabular}{|c|l|l|}
\hline S/N & STATEMENT & Ranking 1-5 \\
\hline 1 & $\begin{array}{l}\text { There is a lack of experience on the part of the practitioners at state governments } \\
\text { in Nigeria }\end{array}$ & \\
\hline 2 & $\begin{array}{l}\text { There are experienced and professional accountants and auditors at state } \\
\text { government levels }\end{array}$ & \\
\hline 3 & There is a lack of forensic Accounting professionals at state governments & \\
\hline 4 & Forensic Accounting is very simple hence can be adopted easily. & \\
\hline 5 & There is a weak educational system at the state government level & \\
\hline
\end{tabular}

\section{Appendix E}

Below are statements about Legal Factors that may influence the applicability of forensic accounting in the NorthWestern States, Nigeria.

Please use the key below to select a number that indicates your level of agreements with the following statements $5=$ Strongly Agree

4-=Agree

3=Undecided

2=Disagree

$1=$ Strongly Disagree 
LEGAL FACTORS

\begin{tabular}{|l|l|l|}
\hline 1. & There is weak litigation support in the prosecution process & \\
\hline 2. & There is always delay at Nigerian courts & \\
\hline 3. & There is a weak judicial system at the state government level & \\
\hline
\end{tabular}

\section{References}

Adefila, J. J., Kasum, A. S., \& Olaniyi, T. A. (2006). The global endemic nature of financial malpractices: An analytical appraisal. African Journal of Management, 1(1), 11-20.

AICPA, A. I. (2006) Audit risk exposure standards. Statements of Auditing Standards.

AICPA. (2008), FVS practice aid 10-1 serving as an expert witness or consultant. New York:

Akhimide, A.E., \& Ekatah, U.R. (2004). The growing relevance of forensic accounting as a tool for combating fraud and corruption: the Nigerian experience. Research Journal of Finance and Accounting, 5 (2), 71-77.

Alabdullah, T.T.Y., Alfadhl, M.M.A., Yahya, S., \& Rabi, A.M.A. (2014). The role of forensic accounting in reducing financial corruption: a study in Iraq. International Journal of Business and Management, 9 (1), 26 - 34. doi:10.5539/ijbm.v9n1p26.

Albrecht, W., Albrecht, C. C. and Albrecht, C. O. (2006) Fraud Examination, 3rd ed., Thomson South-Western

Ayobami, O.O.(2011) Corruption eradication in Nigeria: an appraisal. Library Philosophy and Practice

Baron, R. M., \& Kenny, D. A. (1986). The moderator-mediator variable distinction in social psychological research: conceptual, strategic, and statistical considerations. Journal of Personality and Social Psychology, 51 (6), 11731182.

Bartlett, J. E., Kotrlik, J. W., \& Higgins, C. C. (2001). Organizational research: Determining the appropriate sample size in survey research. Information Technology, Learning, and Performance Journal, 19 (1), 43-50.

Bhavani, G., Amponsah, C.T., \& Mehta, A. (2018). Forensic accounting education in UAE: an exploratory study with diverse stakeholders. Accountancy Business and the Public Interest, 89-105.

Efiong, E. J. (2012). Forensic accounting education: an exploration of level of awareness in developing economiesNigeria as a case study. International Journal of Business and Management. 7(4), 26-34.

Efut, R. C., \& Ema, O. I. (2019). An empirical analysis of the relevance of forensic accounting as a panacea to fraud detection and prevention. International journal of multidisciplinary research, 5 (3), 61 - 66.

Ejike, S. I. (2018). The relevance of forensic accounting: issues in accounting and auditing practice in Nigeria. IOSR Journal of Humanities and Social Science, 23 (7), 17-24. DOI: 10.9790/0837-2307061724.

Ekpo, C.E., Chime, J., \& Enor, J.N. (2016). The irony of Nigeria's fight against corruption: an appraisal Of President Muhammadu Buhari's first eight months in office. International Journal of History and Philosophical Research, 4 (1), 61-73.

Eme, E. J. (2013) An Exploration of Forensic Accounting Education and Practice for Fraud Prevention and Detection in Nigeria. Unpublished Ph.D. Thesis. University De Montfort, Leicester U K.

Enofe, A. O., Afiangbe, S. E., \& Agha, D. I.(2017). Financial management reforms and corruption in Nigerian public sector. International Journal of Advanced Academic Research I Social E Management Sciences, 3 (7), 1-22.

Enofe, A.O., Omagbon, P., \& Ehigiator, F.I. (2015). Forensic audit and corporate fraud. IIARD International Journal of Economics and Business Management, 1(7), 1-10.

Franklyn, O.I., (2013) Automated Auditing and fraud Control in Nigeria: A Case study of the Economic and Financial Crimes Commission Portharcourt. (BSc. Project). Caritas University, Nigeria.

Gbegi, O. O., \& Adebisi, J. F. (2013). The new fraud diamond model: how can it help forensic accountants in fraud investigation in Nigeria public sector? Mediterranean Journal of Social Science, 5 (3), 243-252.

Gray, D. (2008). Forensic accounting and auditing: compared and contrasted to traditional accounting and auditing. American Journal of Business Education, 215 - 126.

Hair, J. F., C. M. Ringle and Sarstedt, M. (2011). PLS-SEM: indeed, a silver bullet. Journal of Marketing Theory and Practice, 18,139-152.

Hubber, D. (2017). The saga of Hubber Vs the American Accounting Association. Forensic accounting and law. Journal of Forensic and Investigative Accounting, 9 (2), 1-10. 
Ijewereme, O.B. (2015). Anatomy of corruption in the Nigerian public sector: theoretical perspectives and some empirical explanations. Public Administration \& Public Policy, 1(16). DOI: 10.1177/2158244015581188.

Imam A. (2013). Forensic Accounting Model for Fraud Prevention and Detection in Nigeria Public Sector. Unpublished (PhD. Thesis). Usman Danfodio University Sokoto, Nigeria.

Imam, A., Kumshe, A. M., \& Jajere, M. S. (2015). Applicability of forensic accounting services for financial fraud detection and prevention in the public sector of Nigeria. International Journal of Information Technology and Business Management, 4(1), 136.

Joseph, A. F., Okeke, M. B., \& Yoko, E. V. (2016). The impact of forensic accounting in fraud detection and prevention evidence from Nigerian public sector. International Journal of Business Marketing and Management, 1(5), $34-40$.

Kumshe, A. M., Umar, I., \& Imam, A. (2018). Prospects of forensic accounting education in Nigeria: a review. SAJRED: Journal of Resources \& Economic Development, 1(1), 74-84.

Kura, K. M. (2014) Organisational Formal Controls Group Norms and Workplace Deviance. Unpublished (PhD. Thesis). University Utara Malaysia.

Melia, S. J. (1991) The expert witness.

Mercy, O.A. (2015) 'The effects of corruption on good governance in Nigeria', International Journal of Development and Sustainability, 4 (3), 292-307.

Muthusamy, G. (2011). Behavioral Intention to Use Forensic Accounting Services for Detection of Fraud by Large Malaysian Companies. Unpublished (PhD. Thesis). Curtin University of technology.

Muthusamy, G., Quaddus, M., \& Evans, R. (2010). Behavioral intention to use forensic accounting services: a critical review of theories and an integrative model. Business Review, 15(2), 42-49.

Nunnally, J. C., \& Bernstein, I. H. (1994). Psychometric Theory, $3^{\text {rd }}$. McGraw-Hill, New York.

Okoye, E.I. \& Gbegi, D.O. (2013). Forensic accounting: a tool for fraud detection and prevention in the public sector (a study of selected ministries in Kogi State). International Journal of Academic Research in Business and Social Sciences, 3(3), 1-19.

Onyekwena, C., \& Ekeruche, M. A. (2020) 'Understanding the impact of the COVID-19 outbreak on the Nigerian economy", Africa in Focus. Retrieved from https://www.brookings.edu/blog/africa-infocus/2020/04/08 (accessed 05 July 2020).

Oyedokun, G. E. (2012). The emergence of forensic accounting and the role in Nigeria's economy. Being a Lecture Delivered at the Annual Week of Nigerian Universities Accounting Students Association, Obafemi Awolowo University Ile-Ife, Nigeria.

Pedneault, S., Rudewicz, F., Sheetz, M., \& Silverstone, H. (2012). Forensic Accounting and Retrieved from Fraud Investigation. $3^{\text {rd }}$ ed. John Wiley \& Sons, Inc.

Ramadhan, S. (2016). Certified accountant's perceptions of forensic accounting education: the case of Bahrain. Internal Journal of Finance and Accounting, 4 (2), 109 -118.

Rezaee, Z., Ha, M., \& Daniel Lo, D. (2014). China needs forensic accounting education. Open Journal of Social Sciences, 2, 59-65.

Rezaee, Z., Lo, D., Ha, M., \& Suen, A. (2016). Forensic accounting education and practice: insights from China. Journal of Forensic E Investigative Accounting, 8(1), 106-119.

Safiyanu, S., Saifullahi, I. S., \& Armayau, S. A. (2019). The effect of forensic accounting investigation in detecting financial fraud: A study in Nigeria. International Journal of Academic Research in Business and Social Sciences, 9 (2), 545-553.

Saito, M., \& Teresa, L. (2016). Global case studies in forensic accounting education: the case of audit failures. Journal of Global Business Management, 12(1), 176 - 183.

Salkind, N. J. (1997) Exploring Research Upper Saddle River.Prentice-Hall, NJ.

Sekaran, U. (2003) Research methods for business: A skill Building Approach, (4th ed.). New Jersey: John Wiley and Sons.

Suleiman, N., \& Ahmi, A. (2018). Mitigating corruption using forensic accounting investigation techniques: the watchdog perspectives. Indian-Pacific Journal of Accounting and Finance (IPJAF), 2(1), 4-25.

Suryanto, T. \& Ridwansyah, R. (2016). The Shariah financial accounting standards: how they prevent fraud in Islamic banking. European Research Studies, 4, 140 - 157. 
Umar, U.H., Haron, M.H., \& Kurawa, J.M. (2021). Detection and prevention of fraud through Islamic inheritance: The case of Islamic inheritance in Nigeria. in Rafay, A. (ed.), Handbook of Research on Theory and Practice of Financial Crimes, IGI Global (Accepted).

Wilson, H. E. Francis, O., Emeka, E. E., \& Loraver, T.N. (2017). Fraud and forensic accounting education: prospects and challenges in Nigeria. International Journal of Business Management, 12(7),146-161.

(C) 2020 by the authors. This article is an open-access article distributed under the terms and conditions of the Creative Commons Attribution (CC BY) license (http://creativecommons.org/licenses/by/4.0/). 